\title{
Leptospirosis: Rising Nuisance for Pets and Threat to Public Health
}

\author{
Prabhusaran $\mathrm{N}^{1^{*}}$, Natarajaseenivasan $\mathrm{K}^{2}$, Joseph PID ${ }^{3}$
}

${ }^{1}$ Department of Microbiology, Trichy SRM Medical College Hospital and Research Centre, Tiruchirapalli, Tamilnadu, India (Affiliated to The Tamilnadu Dr. M.G.R. Medical University, Chennai, India)

${ }^{2}$ Department of Microbiology, School of Life Sciences, Bharathidasan University, Tiruchirapalli, Tamilnadu, India

${ }^{3}$ Department of Microbiology, Karpaga Vinayaga Institute of Medical Sciences and Research Centre, Maduranthagam, Tamilnadu, India

DOI: $\underline{10.36348 / \text { sjpm.2020.v05i04.002 }}$ | Received: 30.03 .2020 | Accepted: 08.04 .2020 | Published: 14.04 .2020

*Corresponding author: Prabhusaran $\mathrm{N}$

Email: leptoprabhu@gmail.com

\section{Abstract}

Leptospirosis is a contemporary zoonotic disease that spread through the direct and indirect contact with animals and its excreta. The rising nuisance of this communicable disease is increasing now days due to handling the pet animals by the family members and allow them upto beds. In most places, placing the pet on the lapses may increase the load of the infections directly from the pet to the humans. The bacterial and serological observations among the infectious individuals are rising steadily but very few eliciting clinical symptoms. Among of the exposures, the immunity scores the individuals and protect from the infection. Eventhough we have good and effective antimicrobials to kill the leptospires and control leptospiral complications, clinicians are not still aware about the pyrexia of unknown origin may be due to leptospirosis. Thus most of the positive cases may leads to chronic state of multiorgan dysfunction to multiorgan failure; in few situations, renal failure, pulmonary and cardiac issues leads to increased mortality. From this review it is requested to all the pet owners to keep your pets in separate place not in your living areas and hopefully asking the clinicians to consider leptospirosis also as one of the suspicions among PUOs.

Keywords: Leptospirosis; pet animals; misdiagnosis; rising nuisance.

Copyright @ 2020: This is an open-access article distributed under the terms of the Creative Commons Attribution license which permits unrestricted use, distribution, and reproduction in any medium for non-commercial use (NonCommercial, or CC-BY-NC) provided the original author and sources are credited.

\section{INTRODUCTION}

Leptospirosis is considered as foremost zoonoses among pet animals that results in multiorgan dysfunction (MOD) to multiorgan failure (MOF) and pathological changes in animals and humans. This communicable disease is found among 150 mammalian species with subclinical observations [1]. Disease is majorly spreading through indirect contact with contaminated urine material. The causative agent belongs to the spirochetal genus Leptospira that are having 21 species, 25 serogroups and 250 serovars. Travellers involved in adventures or outdoor activities including swimming, canoeing, white-water rafting, kayaking or camping is at risk. Occupational peoples including rice and sugar cane fields, mining, rescue workers, veterinarians, military personnels and prisoners are found more risk [2].

The response from clinicians and veterinarians to the initial of the diagnostic service has been gratifying; although many physicians do not yet recognize leptospirosis as disease entity prevalence in many places. The important reasons behind are a. Instructions about leptospirosis in medical colleges is limited

b. Limitations of clinical record given to viral hepatitis only

c. PUOs are not differentiated appropriately and interview the PUO patients related to animal contact is minimal

d. Inadequate and appropriate diagnostic services

\section{Man and animal hosts}

Man and other susceptible animal hosts can be infected by direct and indirect contact with contaminated urine of the infected animals; by consumption of food and water so contaminated and close contact with surface water in which pathogenic leptospires are present. Infection among exposures can occur by invasion of leptopsires through skin abrasions or cut, mucosal surface of conjunctiva, pharynx or nasal passages. The leptospires are harboured in the kidneys of the rodents and other mammalian hosts where these have been resided and proliferated. These are displaying a characteristic affinity in the renal cortex 
further nested in the lumina of the convoluted tubules and then excreted in the urine for long periods of time.

\section{Dogs - a primary scope}

Among the pet animals, dogs stand top and possibilities of transmitting leptospires to humans are readily apparent [3]. Dog handlers (pet owners), kennelmen and veterinarians are most subject to infection from exposure to the contaminated urine. Cuts, abrasions and scratches of the handlers provide suitable routes of entry of leptospires. In some cases, the pet dogs itself create cuts or scratches while playing with them. In nature, the leptospires survive at the $\mathrm{pH}$ environment between 6.8 and 8.6. Eventhough the dogs' urine is acidic in nature, the transmission of leptospires is high to human handlers because of immediate exposure to the fresh urine upon invading a new susceptible host could multiply and cause infection. Female dogs had a significantly higher risk for leptosprial infection [4].

The dogs have been proved as a suitable host for several leptospiral strains, and some of them are not yet reported and recorded (Table 1). Among the infectious serovars, L. Canicola (90\%) is considered as the most frequent leptospiral parasite in dogs followed by L. Icterohaemorrhagiae (10\%). Other serovars like L. Hebdomadis, L. Autumnalis, L. Australis, $L$. Pomona, L. Grippotyphosa and L. Sejroe are isolated and serologically evidenced as infection in dogs.

\section{Cats - source of leptospirosis}

Cats are rare and appear to be mild although very little is known about the disease in this species [1]. It mostly become infected through feeding on natural reservoir hosts, such as when hunting rodents. Cats can also be exposed to urine of cohabiting animals like dogs and rodents (Table 1). Transmission through water contact is less among cats. The common risk factors for leptospirosis in cats include exposure to or drinking from rivers, lakes or streams; roaming on rural properties (because of exposure to potentially infected wildlife, farm animals, or water sources); exposure to wild animal or farm animal species, even if in the backyard; and contact with rodents or other dogs [5].

Experimental infection of cats results in leptospiraemia and leptospiruria, but only mild clinical signs result despite histological evidence of renal and hepatic inflammation. However, recent studies have demonstrated a potential association between feline chronic kidney disease and Leptospira spp infection but the importance of Leptospira as pathogens in cats has to be further investigated. In cats, the different stages of renal insufficiency were observed but didnot show liver involvement [6], but shedding the pathogen though urine; could play an important role in the leptospiral epidemiology [1].

Many cats have antibodies against leptospiral species indicating that infection is common; whereas healthy cats with indoor exposure can shed leptospires and serve as a source of infection to the exposures (other animals or humans) and might have been underestimated [7].

\section{Rabbits}

Rabbits are considered as a less or sometimes absence as reservoir of the pathogenic leptospires before 1970. Later several studies identified the forensics of leptospires in rabbits and the possible of recover the single isolate of leptospires serotype ballum followed by pomona. The serological incidence of showing moderate titer against canicola was observed. The serological study revealed that many small animals including rabbits had leptospiral antibodies to the serogroups Autumnalis and Javanica [8].

The serovars pomona and grippotyphosa are transmitted by rabbits to humans through their urine, feces of the consumption of infected rabbit flesh (Table 1). People who have rabbit in their house are more prone to be infected by inoculation of leptospires in urine of infected animals during cleaning the remnants of foods [9]. Primary intravitreal infection with $L$. Pomona in rabbit eyes gave rise to an acute anterior uveitis of about one week's duration, followed by a chronic inflammation lasting three to six weeks [10].

\section{Birds}

In addition to various diseases spread by birds, susceptible to leptospirosis also found. The bathing of the birds in the contaminated water to be near trees and shrubs so the birds can make a quick getaway should a predator arrive and get leptospirosis, but not so close that the same safe haven gives the predator a place to hide and pounce on the unsuspecting birds; but such study done to assess the exact serovars infected (Table 1). Sometimes in home, the pet birds accidentally exposed to the contaminated water in dog's dish and acquire infection. Prevalence studies have been required to understand the role of birds in harbouring leptospires and transmit to humans $[11,12]$.

Table-1: Common leptospiral serovars in pet animals and birds

\begin{tabular}{|l|l|l|}
\hline \multicolumn{1}{|c|}{ Animals } & \multicolumn{1}{|c|}{ Common serovars } & \multicolumn{1}{|c|}{ Reference(s) } \\
\hline Pet cats & $\begin{array}{l}\text { Icterohaemorrhagiae, Canicola, Copenhageni, } \\
\text { Grippotyphosa, Pomona, Hardjo, Autumnalis, Ballum }\end{array}$ & {$[7,13,14]$} \\
\hline Pet dogs & $\begin{array}{l}\text { Australis, Ballum, Canicola, Copenhagenic, } \\
\text { Grippotyphosa, Icterohaemorrhagiae, Pyrogenes, Sejroe }\end{array}$ & {$[4]$} \\
\hline Pet rabbits & Ballum, Canicola, Icterohaemorrhagiae, Grippotyphosa, & {$[8,9,15,16]$} \\
\hline
\end{tabular}




\begin{tabular}{|c|c|c|}
\hline & Australis, Javanica, Autumnalis, Pomona & \\
\hline Birds & Pomona, Canicola, Icterohaemorrhagiae & {$[11,12]$} \\
\hline \multicolumn{3}{|r|}{$\begin{array}{l}\text { observed as absent, latent, } \\
\text { or severe. Clinically the cases } \\
\text { subacute, acute, subchronic } \\
\text { clinical observations of } \\
\text { iological to pathological are } \\
\text { table } 2 .\end{array}$} \\
\hline
\end{tabular}

Table-2: Stages descriptions of leptospirosis

\begin{tabular}{|l|l|l|l|}
\hline \multicolumn{1}{|c|}{ Period } & \multicolumn{1}{|c|}{ Pathology } & \multicolumn{1}{c|}{ Symptoms } & \multicolumn{1}{c|}{ Diagnosis } \\
\hline $\begin{array}{l}\text { Invasive }- \text { at the time of } \\
\text { entry }\end{array}$ & $\begin{array}{l}\text { Multiply and find their } \\
\text { ways to all organs }\end{array}$ & $\begin{array}{l}\text { Febrile illness and generalized } \\
\text { lethargy and anorexia and } \\
\text { jaundice appears at the end of } \\
\text { this stage }\end{array}$ & $\begin{array}{l}\text { Direct isolation from } \\
\text { blood; direct dark field } \\
\text { microscopy and non- } \\
\text { significant serum titers }\end{array}$ \\
\hline $\begin{array}{l}\text { Hemorrhagic }- \text { within a } \\
\text { week of invasion }\end{array}$ & $\begin{array}{l}\text { Involvement of liver and } \\
\text { spleen; mimicking other } \\
\text { febrile illnesses }\end{array}$ & $\begin{array}{l}\text { Ocular manifestations, } \\
\text { pulmonary involvement; mild } \\
\text { to severe jaundice and } \\
\text { hepatospleenomegaly }\end{array}$ & $\begin{array}{l}\text { Clinical diagnosis is } \\
\text { suitable followed } \\
\text { serological evidences }\end{array}$ \\
\hline $\begin{array}{l}\text { Primary renal }- \text { a week later } \\
\text { nephritic stage) }\end{array}$ & $\begin{array}{l}\text { Find their ways to renal } \\
\text { tubules, characterization } \\
\text { of interstitial nephritis } \\
\text { and nephron obstruction }\end{array}$ & $\begin{array}{l}\text { Clinically detected; apathy, } \\
\text { stomatitis and thirst }\end{array}$ & $\begin{array}{l}\text { Direct isolation from } \\
\text { urine; blood - urea } \\
\text { nitrogen elevated and } \\
\text { agglutination titers are } \\
\text { very high }\end{array}$ \\
\hline $\begin{array}{l}\text { Secondary renal }- \text { after } \\
\text { lapse of several monthes years (secondary } \\
\text { nephritic stage) }\end{array}$ & $\begin{array}{l}\text { Chronic interstitial } \\
\text { nephritis with fibrosis; } \\
\text { acute to chronic renal } \\
\text { damage }\end{array}$ & Uremia and oliguria, & $\begin{array}{l}\text { Possibilities of isolation } \\
\text { in scarce; serum } \\
\text { agglutination titers tend } \\
\text { to below }\end{array}$ \\
\hline
\end{tabular}

Leptospiral infection often has minimal or no clinical manifestations; of the cases in which fever develops, as many as $90 \%$ are undifferentiated febrile illnesses. Because of the variety of clinical symptoms seen in the symptomatic cases, leptospirosis at its onset is often misdiagnosed as aseptic meningitis, influenza, hepatic disease or fever (pyrexia) of unknown origin [2]. Moreover, clinicians may fail to recognize the disease as well as the transmission state of leptospirosis which can occur in the urban setting because it is incorrectly perceived to be a rural disease [8]. Therefore, diagnosis is based on laboratory tests rather than on clinical symptoms alone. In developing countries, laboratory facilities may be inadequate for diagnosis despite a high prevalence of the disease [18].

\section{Symptoms}

Acute febrile illness with headache, myalgia and prostration associated with a history of exposure to infected animals or an environment contaminated with animal urine with one or more of the following - calf muscle tenderness; conjuctival suffusion; anuria or oliguria and/ or proteinuria; jaundice; hemorrhagic manifestations in intestines, lungs; meningeal irritation; nausea; vomiting; abdominal pain and diarrhoea $[18,19]$.

\section{Infectious scenario}

The worldwide prevalence noted is counted to be $41.4 \%$ with $30.1 \%$ in Asia, $25.6 \%$ in Africa and $46.4 \%$ in South Africa. In South India, suspected cases are reported between June and October due to heavy rains and floods. In India, leptospiral outbreaks have been reported related to heavy rainfall in various parts of the country and has been consistently reported from the Andaman and Nicobar islands called Andaman haemorrhagic fever, West Bengal, Maharashtra, Tamilnadu, Kerala and coastal Karnataka [8].

The virulence is attributed to pathogenic proteins which are considered as essential virulence factor. Pathogenesis involves vasculitis following which are direct cytotoxicity and immunological injury resulting in renal failure. Direct examination, polymerase chain reaction, isothermal methods, microscopic agglutination test (MAT) and IgM enzyme-linked immunosorbent assay (ELISA) are diagnostic procedures for leptospirosis. ELISA is the most preferred cost-effective serological method with both sensitivity and specificity of $95 \%$ [20]. MAT is considered as a gold standard test for leptospirosis identification, because this assay has a high sensitivity and allows for the detection of group specific antibodies.

\section{Diagnosis}

Culture of Leptospira is difficult, very laborious and can take up to three months. Therefore, isolation and culture are primarily used for retrospective diagnosis [20]. Doxycycline and azithromycin were used as anti-leptospiral drugs in mild and severe cases of leptospirosis. For children and pregnant women, 
amoxycycline and ampicillin are considered as the better drugs. Further studies are needed regarding clinical and symptomatic differentiation, rapid diagnosis, newer and effective anti-leptospiral drugs, and effective vaccination $[21,22]$.

\section{Prevention and Control}

The key strategies of programme for prevention and control of leptospirosis are

- Updating laboratory training (skill development)

- Strengthening the surveillance of leptospirosis in humans

- Strengthening mobile diagnostic laboratory for need based rural settings

- Creating awareness to the clinicians regarding timely detection and appropriate treatment of patients

- Strengthening patient management facilities in need based rural settings

- Strengthening inter-sectoral coordination at state and district level for outbreak detection, prevention and control of leptospirosis.

Therefore control of leptospirosis required the combined efforts of clinicians, laboratorians, veterinarians and health officers; and any members of this group may observe and diagnose the cases. From this review, it is clearly depicted that the need of maintaining distance of pet animals from the living environment. Dogs and cats that are kept indoors have only a very low risk of becoming infected.

\section{REFERENCES}

1. Weis, S., \& Hartmann, K. (2017). Leptospira infections in cats. Tierarztl Prax Ausg K Kleintiere Heimtiere, 45, 103-108.

2. Prabhusaran, N., Prabhakar, Y.K., Pramila, M., Natarajaseenivasan, K., \& Joseph, P.I.D. (2018). Comparative analysis of immunological markers of leptospirosis and other bacterial infections among normal, high risk and unclassified categories of human flow in hospitals. The Journal of Medical Research, 4, 140-145.

3. Lopez, M.C., Vila, A., Rodon, J., \& Roura, X. (2019). Leptospira seroprevalence in owned dogs in Spain. Heliyon, 27, e02373.

4. Altheimer, K., Jongwattanapisan, P., Luengyosluechakul, S., Pusoonthornthum, R., Prapasarakul, N., Kurilung, A., Broens, E.M., Wagenaar, J.A., Goris, M.G.A., Ahmed, A.A., Pantchev, N., Reese, S., \& Hartmann, K. (2020). Leptospira infection and shedding in dogs in Thailand. BMC Veterinary Research, 16, 89-96.

5. Carlos, E.R., Kundin, W.D., Watten, R.H., Tsai, C.C., Irving, G.S., Carlos, E.T., \& Directo, A.C. (1971). Leptospirosis in the Philippines: feline studies. American Journal of Veterinary Research, 32, 1455-1456.

6. Arbour, J., Blais, M.C., Carioto, L., \& Sylvestre, D. (2012). Clinical leptospirosis in three cats (2001 -
2009). Journal of American Animal Hospital Association, 48, 256-260.

7. Hartmann, K., Egberink, H., Pennisi, M.G., Lloret, A., Addie, D., Belak, S., Baralon, C.B., Frymus, T., Jones, T.G., Hosie, M.J., Lutz, H., Masilio, F., Mosti, K., Radford, A.D., Thiry, E., Truyen, U., \& Horzinek, MC. (2013). Leptospira species infection in cats: ABCD guidelines on prevention and management. Journal of Feline Medicine and Surgery, 15, 576-581.

8. Natarajaseenivasan, K., \& Ratnam, S. (1996). An investigation of leptospirosis in a laboratory animal house. Journal of Communicable Diseases, 28, 153-157.

9. Ris, D.R. (1975). The failure of genus specific serological tests to detect leptospirosis in cattle and rabbits. New Zealand Veterinary Journal, 23, 164166.

10. Witmer, R.H. (1955). Experimental leptospiral uveitis in rabbits. Archives of Ophthalmology, 53, 547-559.

11. Howrath, J.A., \& Renia, M.G. (1958). Comparative studies on experimental avian leptospirosis. Journal of Infectious Diseases, 102, 268-274.

12. Chalquest, R.R. (1957). Experimental infection of birds with Lpetospira Pomona present in bovine urine and preliminary studies on their role in transmission of leptospirosis. Poultry Science, 36, 110-113.

13. Markovich, J.E., Ross, L., \& McCobb, E. (2012). The prevalence of leptopsiral antibodies in free roaming cats in Worcester County, Massachusetts. Journal of Veterinary International Medicine, 26, 688-689.

14. Spribler, F., Jongwattanapisan, P., Luengyosluechakul, S., Pusoonthornthum, R., Prapasarakul, N., Kurilung, A., Goris, M., Ahemd, A., Reese, S., Bergmann, M., Sorsch, R., Klaasen, H.L.B.M., \& Hartmann, K. (2019). Leptospira infection and shedding in cats in Thailand. Transbound Emergency Diseases, 66, 948-956.

15. Shotts, E.B., Andrews, C.L., Sulzer, C., \& Greene, F. (1971). Leptospirosis in cottontail and swamp rabbits of the Mississippi delta. Journal of Wildlife Diseases, 7, 115-117.

16. Balakrishnan, G., Parimal, R., Govindarajan, R., Jayakumar, V., Meenambigai, T.V., \& Murali, B.M. (2008). Occurrence of subclinical leptospirosis in rabbits. Indian Veterinary Journal, 85, 890.

17. Byrne, J.R. (1957). Canine leptospirosis and public health. Public Health Reports, 70, 1229-1236.

18. Prabhusaran, N., Natarajaseenivasan, K., \& Joseph, P.I.D. (2017a). Increasing trends of leptospirosis in Tamilnadu: a clinical epidemiological study - with special emphasis of molecular surveillance and diagnosis. International Journal of Pharma Research and Health Sciences, 5, 1896-1903.

19. Prabhu, N., Natarajaseenivasan, K., \& Joseph, P.I.D. (2015). Survey of leptospiral pathogens 
carried by rodents at different areas of Tiruchirapalli, India. International Journal of Extensive Research, 6, 26-31.

20. Prabhu, N., Natarajaseenivasan, K., \& Joseph, P.I.D. (2014). Importance of serological analysis an interpreter of identifying infecting serovar in patients with leptospirosis. Medical Science, 8, 2731 .
21. Prabhu, N., Joseph, P.I.D., Chinnaswamy, K., Natarajaseenivasan, K., \& Lakshmi, S. (2008). In vitro evaluation of Eclipta alba against serogroups of $L$. interrogans. Indian Journal of Pharmaceutical Sciences, 70, 788-791.

22. Prabhusaran, N., \& Rajajeyakumar, M. (2107b). Scenario of leptospiral vaccines for humans and animals. International Journal of Vaccines and Immune System, 1, 21-23. 